\title{
RESTORATION TRAJECTORY OF CARABID FUNCTIONAL TRAITS IN A FORMERLY AFFORESTED BLANKET BOG
}

\author{
Ainoa Pravia ${ }^{1,2}$, Roxane Andersen ${ }^{2}$, Rebekka E. Artz ${ }^{1}$ \\ Robin J. Pakeman ${ }^{1}$ and Nick A. LitTlewood ${ }^{1}$ \\ ${ }^{1}$ The James Hutton Institute, Craigiebuckler Aberdeen AB15 8QH, UK \\ E-mails: ainoa.pravia@gmail.com; https://orcid.org/0000-0001-6313-8750 \\ rebekka.artz@hutton.ac.uk; https://orcid.org/0000-0002-8462-6558 \\ robin.pakeman@hutton.ac.uk; https://orcid.org/0000-0001-6248-4133 \\ nick.littlewood@hutton.ac.uk; https://orcid.org/0000-0003-4461-8833 \\ ${ }^{2}$ Environmental Research Institute, University of the Highlands and Islands \\ Castle Street, Thurso, KW14 7JD, UK \\ E-mail: roxane.andersen@uhi.ac.uk; https://orcid.org/0000-0002-7782-795X
}

The restoration of peatland function and services on damaged peatland sites is seen as an increasingly important goal for ecological, environmental and societal reasons. Restoration monitoring often places fauna as secondary in importance to water table depth and vegetation, and when carried out, it often focuses on taxonomic indices. The use of functional traits, however, can be a complementary approach that clarifies mechanistic links between biodiversity and ecosystem functioning.

This study was conducted in large blanket bog site in northern Scotland, using a space-for-time-substitution of restoration sites from which conifer plantations had been removed 2-18 years previously. Carabid beetles were sampled by pitfall trapping in each of three treatments (undamaged bog, restored, afforested). Functional trait data were summarised from available literature.

The study found that sites under forestry had different functional traits than blanket bog, and that restoration initially shifted the suites of functional traits away from both forested and open blanket bog. However, no other change in functional traits was observed, and after two decades, restoration sites continue to support carabid communities with higher dispersal capacity and more diurnal activity than the open bog. On the other hand, the functional diversity measures used in this study failed to differentiate the different treatments and further analyses suggest that environment, rather than traits, better explain carabid beetle composition following restoration of formerly afforested blanket bog. In particular, the lack of recovery of typical blanket bog vegetation and microhabitat following felling to waste and drain blocking appear to limit carabid functional recovery.

Keywords: blanket bog restoration, carabids, conifers, functional traits, RLQ analysis.

\section{INTRODUCTION}

Ecological restoration has become one of the most cost-effective management techniques for the accelerated recovery of damaged or degraded habitats (BuLlock et al. 2011) as society recognises the value of the goods and services provided by undamaged ecosystems (GHermand et al. 2010). Whilst it 
is implicitly acknowledged that our ability to restore functional peatlands will increase with understanding of key interactions and feedback mechanisms linking different components of the ecosystem, this is not always reflected in monitoring schemes (Rochefort \& ANDERSEn 2017). Indeed, the monitoring of peatland restoration frequently focuses on measurement of water table level, vegetation and physico-chemical elements (HAAPALEHTo et al. 2011), with faunal components often being seen as of secondary importance (RAMCHUNDER et al. 2012).

When carried out, faunal monitoring often relies on species diversity indices (SPITZER \& DANKs 2006), which commonly find links with drivers of decline (Desrochers \& VAN Duinen 2006), or are linked to particular species key for the ecosystem function of interest to management. In species-poor blanket bog assemblages, carabids are an integral element of food webs. Many are arthropod predators within above-ground arthropod communities (Екsснмітт et al. 1997), others contribute to decomposition and nutrient cycling (HunTER et al. 2003), herbivory and seed dispersal (KulKarni et al. 2015) and they, in turn, are prey for upland insectivorous birds (BuchanAN et al. 2006).

Although there is a plethora of studies looking at the relationship between arthropods and particular ecosystem functions in a range of habitats (e.g. Belovsky \& Slade 2017), taxonomic approaches alone have a limited scope as do not allow for the identification of mechanistic links between biodiversity and ecosystem functioning (Mouchet et al. 2010, GAGIC et al. 2015) ecosystem functioning and environmental constraints. Many indices of functional diversity have been published but we lack consensus about what indices quantify, how redundant they are and which ones are recommended. 2. This study aims to build a typology of functional diversity indices from artificial data sets encompassing various community structures (different assembly rules, various species richness levels. By contrast, functional frameworks do, as they are based on the use of species functional traits (FTs) and functional diversity (FD, Petchey \& Gaston 2006, Villéger et al. 2010 ), which is the variation in the degree of expression of functions between different individuals of a population, between populations of the same species, between species or between ecosystems (GARNIER et al. 2016).

Functional approaches have become a useful tool to aid understanding of community structure and assembly rules. For instance, the use of FTs in research can help visualise an organism's response to changing environmental conditions (De Bello et al. 2010), potentially offering more ecologically meaningful conclusions than taxonomic approaches alone (McGill et al. 2006). However, the application of trait-based approaches also poses limitations (McGill et al. 2006, Ретсhey \& Gaston 2006), as species traits are not always known or readily available in the literature, particularly for those species that 
are proven to be taxonomically challenging or difficult to sample (GERLACH et al. 2013). FD components (such as functional richness, functional evenness, functional divergence) are more sensitive to community assembly rules than to species richness, yet are still influenced by species richness to some extent (Mouchet et al. 2010). They can be useful for addressing a number of questions regarding ecological determinants of FD (e.g. Weiner et al. 1998), ecosystem processes (Díaz \& CABIDo 2001), and mechanistic links between species and ecosystems such as niche complementarity (MAson et al. 2005) and other assembly processes. Consequently, using a holistic approach that incorporates both taxonomic and functional biodiversity approaches (FounTAIN-Jones et al. 2014), improves the understanding of how carabids respond to restoration in peatlands, and how this response affects other components of the ecosystem. In recent years, functional approaches have been particularly useful to improve our understanding of carabid ecology, and have been shown to be especially relevant in the study of carabid distribution (MAGURA 2017, Gallé et al. 2019) and species flows (MAGURA \& Löver 2019) across habitat gradients, land use changes (BAULeChNer et al. 2019) and trait syndromes associated with forests (Nolte et al. 2017).

Here, we used a functional trait approach in the specific case of blanket bog undergoing restoration following drainage and afforestation, which involves mechanical tree harvesting and drain blocking. Specifically we aimed to investigate whether a functional approach can provide mechanistic links between carabid community structure and habitat use, and can be used to inform restoration management. We aimed to: 1) examine the restoration trajectory of carabid functional traits along a restoration chronosequence of blanket bog; 2 ) evaluate the variation of FD components across the restoration matrix (forestry, restoration and blanket bog); and 3) assess changes in functional community structure across the different stages of restoration in formerly afforested blanket bog. Overall, we anticipate that suits of traits, or trait syndromes, will be associated with different stages of the restoration process. More specifically, we hypothesise that: 1) carabid functional traits should display a non-linear restoration trajectory as species traits are intrinsic to the species recorded from those carabid communities. As restoration began, primary colonisers would be expected to be habitat generalists, whilst certain habitat structure conditions need to be achieved for specialists to return; 2) the disturbance created by afforestation and subsequent restoration will have a greater impact on habitat specialist species, because of their specific ecological requirements and often narrow operating niches; and 3) changes in habitat structure should filter carabid community composition, primarily via species microhabitat preferences. 


\section{MATERIALS AND METHODS}

\section{Site description $\mathcal{E}$ study design}

The study sites were located in the RSPB Forsinard Flows National Nature Reserve (NNR; latitude 58.357, longitude -3.897) situated in the county of Sutherland in northern Scotland, and established in 1991. Following extensive plantation of non-native conifers Sitka spruce (Picea sitchensis) and Lodgepole pine (Pinus contorta) in the 1980s, ongoing restoration efforts since 1997 have created a series of restoration sites, aged 18 years (restored in 1997/98) to 1 year (restored 2017/2018) since tree removal. The NNR also comprises areas of undamaged open blanket bog and remaining conifer plantations.

For our study, we used a space-for-time substitution based on six restoration age classes $(2,10,11,12,13$ and 18 years since onset of restoration management) along with open blanket bog and remaining conifer plantation (Fig. 1). As restoration was spread across 18 years, trees were at different stages of growth at felling. A range of tree removal methods have been used in Forsinard over the years, but for this study we chose sites that had undergone similar treatments: drainage ditches that had been created at the time of planting were blocked, and trees were felled and left on site, largely laid along ditches. The exception being the most recent restoration treatment (R2). In R2 timber was removed but substantial quantities of brash remained on site (trees laid along ditches and brash scattered around the treatments), resembling the areas felled in earlier years. The same sites were also used in a study looking at water chemistry changes following restoration (GAFFney et al. 2018).

All sites sampled were considered large enough to host a characteristic carabid assemblage. For forest and restoration sites, we sampled within single forest blocks, defined as individual management units within larger forest areas that were separated by rides typically up to $6 \mathrm{~m}$ wide. Thus, whilst sample sites had a minimum extent of $113 \mathrm{~m}^{2}$ and a mean of $162 \mathrm{~m}^{2}$, they were surrounded by land managed in the same way. Each sample site was a minimum $100 \mathrm{~m}$ from the closest transition to a different habitat class or restoration age and were thus sufficiently distant to be considered independent from each other $(>50$ $\mathrm{m}$, Magura et al. 2003). There were four replicate sampling plots per restoration age class, five in open blanket bog and five in conifer plantation.

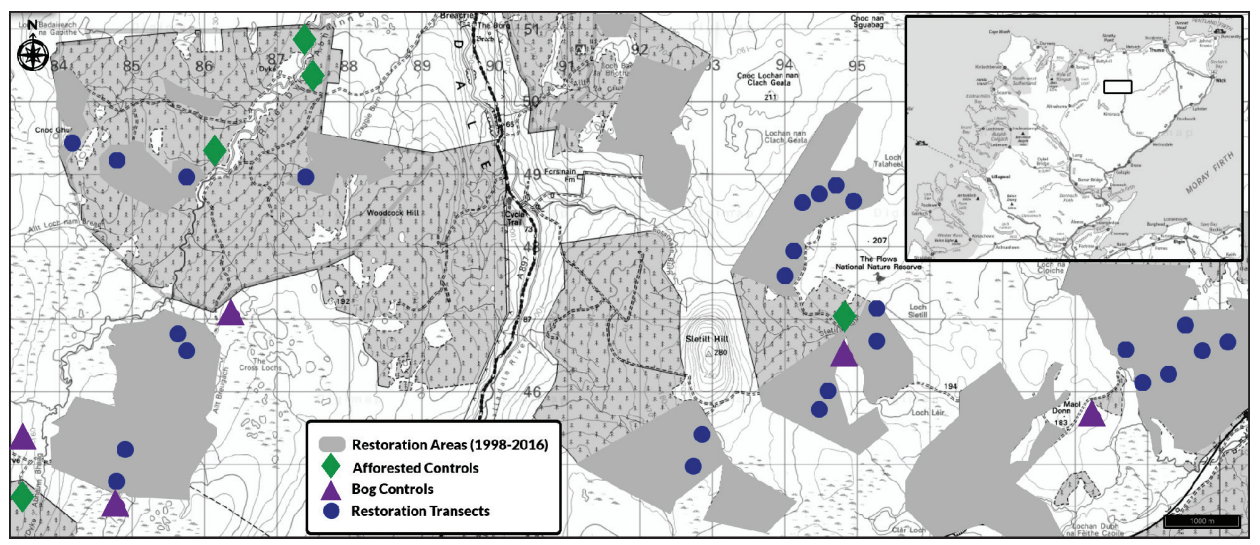

Fig. 1. Map of experimental design in Forsinard 
Table 1. Carabid species included in the study.

\begin{tabular}{lc}
\hline Species & Code \\
\hline Carabus glabratus Paykull, 1790 & CGLA \\
Carabus problematicus Herbst, 1786 & CPRO \\
Cychrus caraboides Linne, 1748 & CYCA \\
Dyschirius globosus Herbst, 1784 & DGLO \\
Pterostichus adstrictus Eschscholtz, 1823 & PAD \\
Pterostichus niger Schaller, 1783 & PNIGE \\
Pterostichus diligens Sturm, 1824 & PDIL \\
Notiophilus biguttatus Fabricius, 1779 & NBIG \\
Notiophilus germinyi Fauvel in Grenier, 1863 & NGER \\
Leistus terminatus Panzer, 1793 & LTE \\
Loricera pilicornis Fabricius, 1775 & LPIL \\
Nebria salina Fairmaire \& Laboulbene, 1854 & NSAL \\
Patrobus assimilis Chaudoir, 1844 & PASS \\
Pterostichus nigrita Paykull, 1790 & PNIGR \\
Trechus obtusus Erichson, 1837 & TOB \\
Agonum fuliginosum Panzer, 1809 & AFU \\
Agonum ericeti Panzer, 1809 & AER \\
\hline
\end{tabular}

\section{Carabid sampling}

Carabids were sampled using pitfall trapping, which provide a measure of species activity-density. Each trap consisted of a plastic cup $(500 \mathrm{ml}, 95 \mathrm{~mm}$ diameter, $115 \mathrm{~mm}$ depth). Each pitfall trap was part-filled with propylene glycol and fitted with a wire mesh dome inside to aid the escape of vertebrates. A transect of 4 pitfall traps, $5 \mathrm{~m}$ apart, was set in the centre of each plot on the original surface of the peat following a random orientation. Pitfall traps were emptied and refilled with propylene glycol at 3-week intervals between mid-May and mid-September. All adult carabid specimens were identified to species (LuFF 2007), except Pterostichus nigrita and P. rhaeticus were classified as a pseudospecies and pooled together for analyses (Table 1).

\section{Vegetation sampling}

Abundance of dwarf shrubs (SHRB), grasses/sedges (GRSED), bare peat (BPEAT) and litter (LIT) were estimated from photographs covering approximately $1 \mathrm{mx} 1 \mathrm{~m}$ centred on each pitfall trap, and using cover classes $(0=$ absent, $1=$ sparse cover, $2=50 \%$ coverage, $4 \geq 50 \%$ coverage. Abundance of Sphagnum (SPH) and other mosses (MOSS) was estimated in the visually in the field in a $1 \mathrm{~m} \times 1 \mathrm{~m}$ area centred on each trap, by following slightly different cover classes $(0=$ absent, $1 \leq 10 \%, 2=10-50 \%, 3=50-75 \%, 4 \geq 75 \%)$. 


\section{Soil variables}

Soil moisture (Mmv) and soil temperature (TA) were measured by inserting the sensor (Hanna moisture meter and thermometer respectively) on the ground at a random point within $30 \mathrm{~cm}$ of the pitfall trap on each collection occasion and values were averaged per transect. Soil water $\mathrm{pH}(\mathrm{PH})$ was measured only once during the season on a 1:5 soil/ deionised water suspension (McLean 1982).

\section{Landscape variables}

Transect coordinates (NOR, EAST) were recorded with a handheld Garmin GPS. Plot perimeter (PPER) and plot area (PAR) along with distance to undamaged bog (DBOG), forestry (DFOR), forestry tracks (DROAD) and bog pools (DPOOL) were estimated from Google Earth Pro maps. The degree of isolation between open blanket bog habitat patches and restoration areas (fCDEX) was assessed on a scale from 1, a sampled polygon with all sides surrounded by blanket bog, to 4 , a sampled polygon with all sides surrounded by forestry or restoration areas.

\section{Selection of carabid functional traits (FTs)}

Carabid FTs selected for this experiment were those thought to be sensitive to landscape changes and to play a role in the regulation of ecological functions in the ecosystem (GERISCH et al. 2012, GERISCH 2014) still little is known about the functional consequences of such changes. Functional diversity can be used to revealing more mechanistically the disturbance effects on communities by considering the richness and the distribution of traits among the species. Here we analyzed the response of functional and species diversity of ground beetles to flood disturbance to better understand the functioning of alluvial invertebrate communities. Ground beetles were sampled in periodically flooded grasslands along the Elbe River in Germany. We used generalized linear mixed effects models to unveil the relationships between flood disturbance, species and functional diversity, respectively. We measured different components of functional diversity (functional richness, evenness, dispersion, and divergence. For species displaying polymorphism for some traits, information relating to Scottish or British populations was used whenever possible. In total, 17 traits were selected: six morphological traits, six physiological traits, four phenological traits and one ecological performance trait (Table 2). Morphological traits and wing development were measured from specimens collected during the sampling campaign in 2016 (wing development was coded following RIBERA et al. 2001), and other traits were obtained from literature. For the PNIGR complex (P. nigrita and P. rhaeticus), both species shared the same trait values for all FTs considered, and thus they were treated as one group. Singleton species for which a large number of trait values were not available (T. rubens, A. lunicollis, B. quadripustulatum) were excluded from the analysis. In the single case of A. fuliginosum, where a FT was unknown, it was assumed to be similar to the most closely related species (as in Ribera et al. 2001 and habitat adversity or stress as characterized by elevation and vegetation structure. The underlying environmental axes and the relationships of the morphology and life traits of the species with them were investigated using RLQ analysis, a multivariate ordination method able to relate a species trait table to a site characteristics table by way of a species abundance table. The first environmental axis was highly statisti- 
cally significant and explained most of the variability. It was strongly negatively related to the intensity of land management, and positively related to increasing elevation and a set of variables reflecting vegetation stress. Two predictions were tested and found to be valid in the studied system: in highly managed lowland sites species were smaller, and the frequency of macropterous species (with better dispersal abilities).

Table 2. Carabid functional traits. Morphological traits were measured from specimens collected at Forsinard. Traits were available in the literature: 1) Ribera et al. 1999, 2001;

2) Cole et al. 2002; 3) Turin \& Den Boer 1988, De Vries \& Den Boer 1989, New 2004, Noordijk et al. 2008; 4) Ings \& Hartley 1999, Forsythe 2000, Stockan I. 2014, BargmanN I. 2016; 5) Thiele 2012, Stockan et al. 2014, Brigić et al. 2014a; 6) Turin \& Den Boer 1988, Koivula et al. 2002, Koivula \& Vermeulen 2005 and Brigić et al. 2014b. Attributes marked with a * were the fuzzy-coded carabid traits used in the final RLQ analysis.

\begin{tabular}{|c|c|c|}
\hline Code & Type & Trait \\
\hline BAV & Morphological & $\begin{array}{l}\text { Body length (head length }+ \text { pronotum length + elytra } \\
\text { length) }\end{array}$ \\
\hline HEAD.W & & Head width from eye to eye at mid-eye length \\
\hline HEAD.L & & Head length from behind the eyes to the mandibles \\
\hline PRONO.L & & Pronotum length along the middle line \\
\hline ELYTRA.L & & Elytra length from scutellum to the largest elytron tip \\
\hline LEG & & $\begin{array}{l}\text { Tibia (from bottom to coxa) + Femur (from bottom of } \\
\text { tibia to top of tarsi) + Tarsi (no claws) }\end{array}$ \\
\hline FPREF $^{1,2}$ & Physiological & $\begin{array}{l}\text { Food preference: (1) specialist feeder*; (2) general preda- } \\
\text { tor; (3) mixed diet }\end{array}$ \\
\hline $\mathrm{WDEV}^{1,2}$ & & $\begin{array}{l}\text { Wing development: (1) apterous/brachypterous*; (2) } \\
\text { dimorphic }^{*} \text {; (3) macropterous* }\end{array}$ \\
\hline $\mathrm{LOCO}^{2}$ & & Type of locomotion: (1) runner*; (2) pusher; (3) digger \\
\hline $\mathrm{POD}^{3}$ & & Power of dispersal: (1) low*; (2) intermediate*; (3) high \\
\hline MOIST $^{4}$ & & $\begin{array}{l}\text { Moisture preference: (1) hygrophilous; (2) mesophilous; } \\
\text { (3) xerophilous }\end{array}$ \\
\hline LIGHT $^{5}$ & & $\begin{array}{l}\text { Light preference: (1) shaded (canopy) habitats*; (2) light } \\
\text { (open) habitats }\end{array}$ \\
\hline $\mathrm{OVW}^{1}$ & Phenological & $\begin{array}{l}\text { Overwintering stage: (1) only adults; (2) adults \& larvae*; } \\
\text { only larvae }\end{array}$ \\
\hline CYCLE $^{1}$ & & Duration of life cycle: (1) one year; (2) two years \\
\hline DIEL $^{1}$ & & $\begin{array}{l}\text { Diel activity: (1) only diurnal*; (2) diurnal \& nocturnal*; } \\
\text { (3) nocturnal* }\end{array}$ \\
\hline $\mathrm{BRE}^{1}$ & & $\begin{array}{l}\text { Breeding season: (1) spring; (2) summer; (3) autumn/ } \\
\text { winter* }\end{array}$ \\
\hline $\mathrm{HPREF}^{6}$ & $\begin{array}{l}\text { Ecological } \\
\text { performance }\end{array}$ & $\begin{array}{l}\text { Habitat preference: (1) generalist/eurytopic; (2) forest; (3) } \\
\text { specialist/stenotopic }^{*}\end{array}$ \\
\hline
\end{tabular}




\section{Functional indices}

The FD facets used in this study were aimed at weighting the intrinsic effect of each species according to its abundance in order to reflect its contribution to ecosystem functioning (Grime 1998). We partitioned FD into four primary components: functional richness, functional evenness, functional divergence (MAson et al. 2005; VilléGER et al. 2010), and functional dispersion (LaLiberté \& Legendre 2010).

\section{Statistical analyses}

All statistical analyses were performed with R v3.4.1 (R Core TeAm 2017).

Pitfall trap collections were standardised by pooling species/taxa abundance in all 4 transect-traps and obtaining an average activity/density. Count data were transformed using Hellinger (Legendre \& GaLlagher 2001).

Principal response curve (PRC), a form of redundancy analysis focusing on the interaction between time and treatment performed with the prc function in the vegan package (ОкsАNen et al. 2018), was used in a space-for-time substitution approach to evaluate the restoration trajectory of carabid functional traits. We used community weighted means (CWMs) as response variables (Pетснеу \& GAston 2006) created with the package FD (LALIBERTÉ et al. 2015), and these were log and total transformed with the decostand function in vegan. PRC requires the use of a control defined a priori, to which treatments are compared. In this case, open blanket bog was used as a control, whilst forestry was used as the first stage of restoration (R0), and all other restoration age classes where the response treatments over time (R2-R18, signifying years since onset of restoration management). The significance of the results were tested by in a Monte Carlo test with 999 permutations (TER BRAAK \& ŠMILAUER 2002). The functional trait scores allow the interpretation of the PRC at the trait level, showing the influence of certain functional traits on the overall carabid trait response between the control and the treatments.

FD facets were calculated with the FD package. In order to evaluate if FD components differed between treatments, a null distribution model (Gotelli \& Graves 1996) was used to compare each FD facet in communities with different species richness and different species pools. We generated 999 random assemblage matrices for each FD facet using a matrix swap randomisation null model (MANLY 1995), where all data matrix values are randomised but row and column sums are fixed. Standardised effect sizes (SES) were used to assess the direction and magnitude of the deviations from null model expectations, and were calculated by the formula: SES = Meanobserved-Meanexpected/SDexpected. In order to compare SES between treatments, p-values were calculated from quantile scores with a two-tailed test where $\alpha=0.05$ indicates that observed $\mathrm{p}$-values must be equal/less than 0.025 for a lower than expected FD, but equal/greater than 0.975 for higher than expected FD (SWENSON 2014). Larger observed values than expected usually indicate competitive relationships whereas smaller observed values than expected by the null distribution indicate environmental filtering.

The three-table ordination analysis RLQ was used to tease out functional trait-environment relationships in peatland carabids with package ade4. An iterative RLQ was carried out before the final RLQ analysis in order to identify the most parsimonious traitenvironment model and avoid an over-fitted model (BERNHARDT-RöMERMANN et al. 2008) by following PaKeman (2011). The traits detected by the iterative RLQ were considered optimal for describing the response of the carabid community and traits to the given envi- 
ronmental conditions in the restoration of afforested bog. RLQ and fourth corner analysis (DrAY et al. 2014) were then applied to carabid traits, carabid abundances and environmental variables. As variables were measured with different statistical units (species and samples), randomisation procedures were applied for fourth corner analysis (DRAY \& LEgENdRe 2008). A sequential approach with low Type I error (model 6, Ter BraAK et al. 2012) tested for significance in the global relationship between traits and environment. An adjusted p-value procedure followed (false discovery rate method, BENJAMINI \& HOCHBERG 1995), and a significant association was found if the largest of the two p-values obtained was lower than $\alpha=0.05$.

\section{RESULTS}

\section{Restoration trajectory}

There was an initial difference in carabid FTs between forestry and blanket bog (Fig. 2). FTs shifted away from the bog reference immediately after tree felling (between age 0 and 1), and remained different from the bog reference without any apparent changeover time along the chronosequence (PRC $1=11 \% ; \mathrm{F}=20.29$; $\mathrm{p}$-value $=0.001$ ). The second axis of the PRC was not significant (PRC $2=1.12 \%, F=2.07, \mathrm{p}=0.078)$, suggesting that there were no other significant temporal patterns separating FTs between the treatments and the blanket bog reference. The FTs associated with a positive score along the vertical axis in Figure 2 consistently have higher frequency in restoration treat-

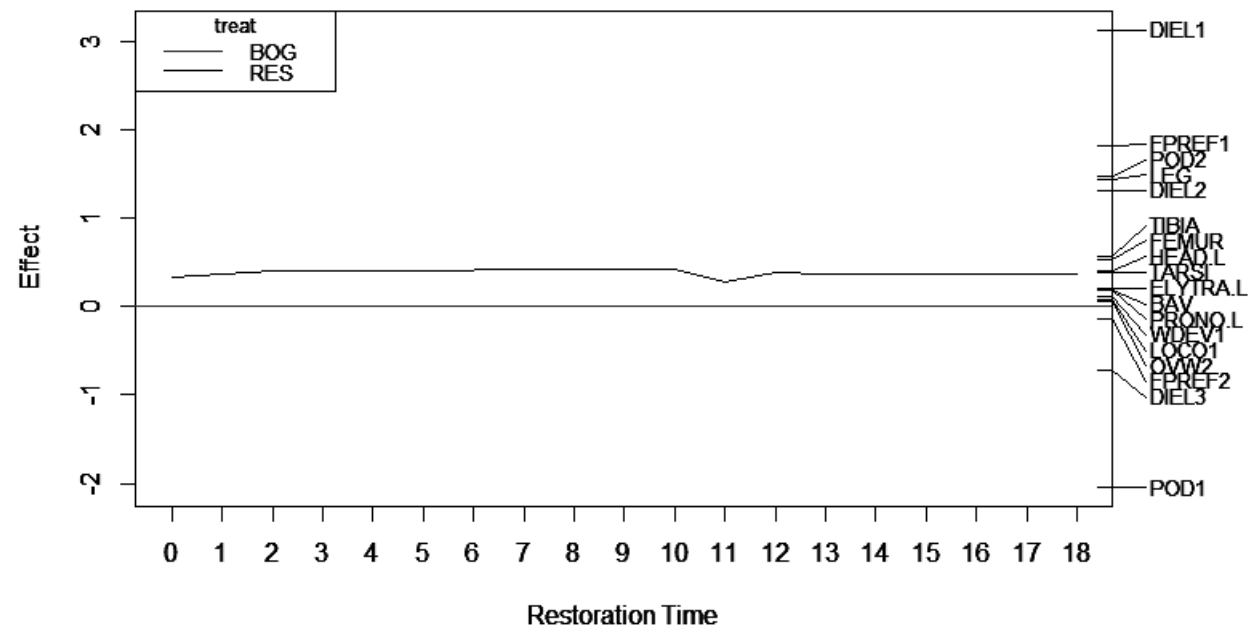

Fig. 2. PRC for the restoration trajectory of carabid FTs. The $Y$ axis represents the PRC scores at each restoration age class; the $\mathrm{X}$ axis is the time since restoration began ( $\mathrm{t}$ in years). Open blanket bog (control) is the grey line; the restoration trend is the solid black line, with forestry (unfelled conifer plantations) acting as the first point of restoration $(t=0)$. Functional trait codes are found in Table 2. Only best fitting FTs are shown 
ments compared with the bog control (18.4\% of the traits used), whilst FTs with negative scores had lower frequency in restoration treatments $(5.2 \%$ of the traits) compared with the bog control. Hence, species with limited dispersal capability (POD1) and nocturnal diel activity (DIEL3) dominated in open blanket bog compared with restoration areas. In contrast, diurnal (DIEL1), or both nocturnal and diurnal species (DIEL2) were favoured during restoration. Intermediate dispersal power (POD2) showed a higher frequency in restoration treatments than in open bog (Fig. 2), but the proportion of each attribute was highly variable across restoration treatments.

\section{Functional diversity measures}

When looking at treatments ( $\mathrm{p}$-values averaged per treatment), none of the functional components of FD indicated significant modification in functional structure for carabid communities (Table 3). For individual sites, significant results $(p>0.975$ or $p<0.025)$ were observed at a similar rate to that of expected stochasticity. Thus these particular functional traits may be of limited use for explaining assembly rules of carabid communities in open blanket bog restoration.

\section{Carabids, functional traits and environmental variables}

The iterative RLQ process selected fifteen explanatory fuzzy coded traits for the final RLQ analysis: nine physiological traits and six morpho/pheno/ ecological performance traits (Table 3).

The global test for trait-environment relationships was not significant (model 2, $\mathrm{p}<0.01$; model $4, \mathrm{p}=0.79$ ), suggesting that environment alone drives carabid beetle composition in the restoration of formerly afforested

Table 3. Standardised effect sizes (SES) for FD values per site. FRic - functional richness; FDiv - functional divergence; FEve - functional evenness; FDis - functional dispersion. Bold values indicate significant $\mathrm{p}$-values for a two-tailed test testing for SES values larger (above 0.975 ) or lower (below 0.025) than expected when comparing our observed values with the values obtained with the null distribution.

\begin{tabular}{lcccccccc}
\hline Site & \multicolumn{3}{c}{ FD Indices (SES) } \\
\hline & FRic & FDiv & FEve & FDis & FRic & FDiv & FEve & FDis \\
B2 & 0.50 & 2.38 & -1.12 & -0.92 & 0.318 & $\mathbf{0 . 9 7 6}$ & $\mathbf{0 . 0 1 0}$ & 0.891 \\
B5 & 0.21 & 1.88 & -0.63 & -0.84 & 0.360 & 0.885 & 0.030 & 0.676 \\
B6 & -0.74 & 0.42 & -0.27 & 0.51 & 0.693 & 0.181 & 0.317 & 0.589 \\
B7 & 2.73 & 2.75 & -0.37 & -1.04 & $\mathbf{0 . 0 1 4}$ & 0.967 & $\mathbf{0 . 0 0 6}$ & 0.622 \\
B8 & 1.68 & -0.26 & 0.47 & -0.36 & 0.060 & 0.562 & 0.588 & 0.309 \\
\hline
\end{tabular}


Table 3 (continued)

\begin{tabular}{|c|c|c|c|c|c|c|c|c|}
\hline Site & & FD Ind & es (SES) & & & $p-v$ & ues & \\
\hline TA98-1 & -0.51 & -0.21 & -0.84 & -0.04 & 0.660 & 0.404 & 0.560 & 0.813 \\
\hline TA98-2 & 0.14 & -0.43 & -0.32 & 0.82 & 0.445 & 0.173 & 0.640 & 0.566 \\
\hline TA98-3 & -0.86 & 0.46 & -1.09 & -0.45 & 0.751 & 0.619 & 0.314 & 0.916 \\
\hline TA98-4 & -0.92 & -0.64 & -0.51 & -0.35 & 0.814 & 0.571 & 0.728 & 0.663 \\
\hline IM03 & 2.58 & -0.51 & -0.25 & -0.05 & 0.015 & 0.396 & 0.675 & 0.531 \\
\hline RA03-1 & -0.91 & 0.32 & -0.17 & 0.15 & 0.824 & 0.386 & 0.394 & 0.522 \\
\hline RA03-2 & -0.78 & -0.13 & -0.41 & -0.86 & 0.805 & 0.970 & 0.598 & 0.701 \\
\hline RA03-3 & -0.89 & 0.43 & -0.16 & -0.88 & 0.751 & 0.859 & 0.343 & 0.488 \\
\hline CL04-1 & 1.83 & -0.72 & 0.01 & 1.88 & 0.077 & 0.060 & 0.766 & 0.393 \\
\hline CL04-2 & -1.07 & 0.46 & -1.02 & -0.83 & 0.858 & 0.859 & 0.318 & 0.862 \\
\hline IM04 & 0.36 & -0.50 & 0.72 & -0.10 & 0.282 & 0.351 & 0.677 & 0.202 \\
\hline TA04 & -0.98 & -0.61 & -0.41 & -0.49 & 0.825 & 0.596 & 0.726 & 0.608 \\
\hline CL05-1 & -1.21 & 2.45 & -0.16 & 1.54 & 0.857 & 0.054 & 0.007 & 0.544 \\
\hline CL05-2 & -0.72 & 0.36 & 0.08 & -0.45 & 0.914 & 0.535 & 0.372 & 0.453 \\
\hline LE05 & -0.06 & 0.56 & 0.16 & -0.30 & 0.407 & 0.455 & 0.282 & 0.383 \\
\hline TA05 & -1.03 & -0.14 & 0.12 & -0.62 & 0.892 & 0.740 & 0.553 & 0.411 \\
\hline LE06 & -1.22 & -0.05 & -0.68 & -0.23 & 0.883 & 0.525 & 0.538 & 0.756 \\
\hline RA06-1 & -0.10 & 0.66 & -0.59 & -0.35 & 0.482 & 0.516 & 0.257 & 0.727 \\
\hline RA06-2 & -1.29 & -0.25 & -0.16 & 0.20 & 0.892 & 0.287 & 0.571 & 0.490 \\
\hline RA06-3 & 0.10 & -0.27 & -0.79 & 0.32 & 0.336 & 0.226 & 0.591 & 0.825 \\
\hline DK1 & 0.91 & -1.12 & -0.68 & 0.52 & 0.214 & 0.196 & 0.876 & 0.758 \\
\hline DK2 & 0.78 & 0.43 & -0.21 & -0.25 & 0.258 & 0.504 & 0.355 & 0.505 \\
\hline DK6 & 1.05 & -0.84 & -0.76 & -0.52 & 0.146 & 0.653 & 0.786 & 0.753 \\
\hline DK7 & 1.21 & -1.11 & 0.45 & -0.62 & 0.133 & 0.759 & 0.875 & 0.238 \\
\hline F3 & 1.29 & 0.42 & -1.32 & -0.54 & 0.084 & 0.653 & 0.346 & 0.961 \\
\hline F5 & 0.67 & -1.25 & -0.74 & -0.36 & 0.245 & 0.584 & 0.891 & 0.756 \\
\hline F6 & 1.30 & -0.61 & -1.22 & -0.31 & 0.096 & 0.549 & 0.712 & 0.907 \\
\hline F7 & 1.02 & -0.42 & 0.70 & 1.50 & 0.125 & 0.093 & 0.607 & 0.270 \\
\hline F8 & 0.88 & -1.62 & -1.16 & 1.89 & 0.177 & 0.041 & 0.968 & 0.895 \\
\hline
\end{tabular}

blanket bog. In addition, measured FTs are not a driver of differences in species affinities with present environmental conditions. Most of the RLQ variation was explained by the first axis $(76 \%)$, whilst the second axis contributed $9 \%$. Within the first axis, most of the variation is explained by environmental variables (R ratio, 94\%), whilst FTs explain a lesser proportion (Q ratio, 50\%). 
The new set of sites-species scores had a correlation of $60 \%$ along Axis 1 (Correlation $\mathrm{L}$ ), with a forestry-restoration-bog control gradient.

Bogs were often surrounded by other bogs and located further away from forestry than any restoration or forestry treatments (Fig. 3), with high cover of Sphagnum mosses. They were primarily characterised by carabid species with dimorphic wing forms, such as $A$. ericeti, although weaker associations with bog were found for $P$. nigrita/rhaeticus, A. fuliginosum and $P$. diligens. Thus, open blanket bog is best described by tyrphobionts (peatland specialist species) and some tyrphophiles (species with affinity for wet upland or open habitats), all of which are dimorphic wing form species.

In contrast to bog, restoration and forestry sites tended to be surrounded by other damaged habitats (Figs $3 a, c$ ). There was significant overlap in midto late restoration treatments, supporting the PRC results showing non-convergence with the bog reference target. R18 samples are not particularly associated with any carabid species, but are somewhat characterised by greater

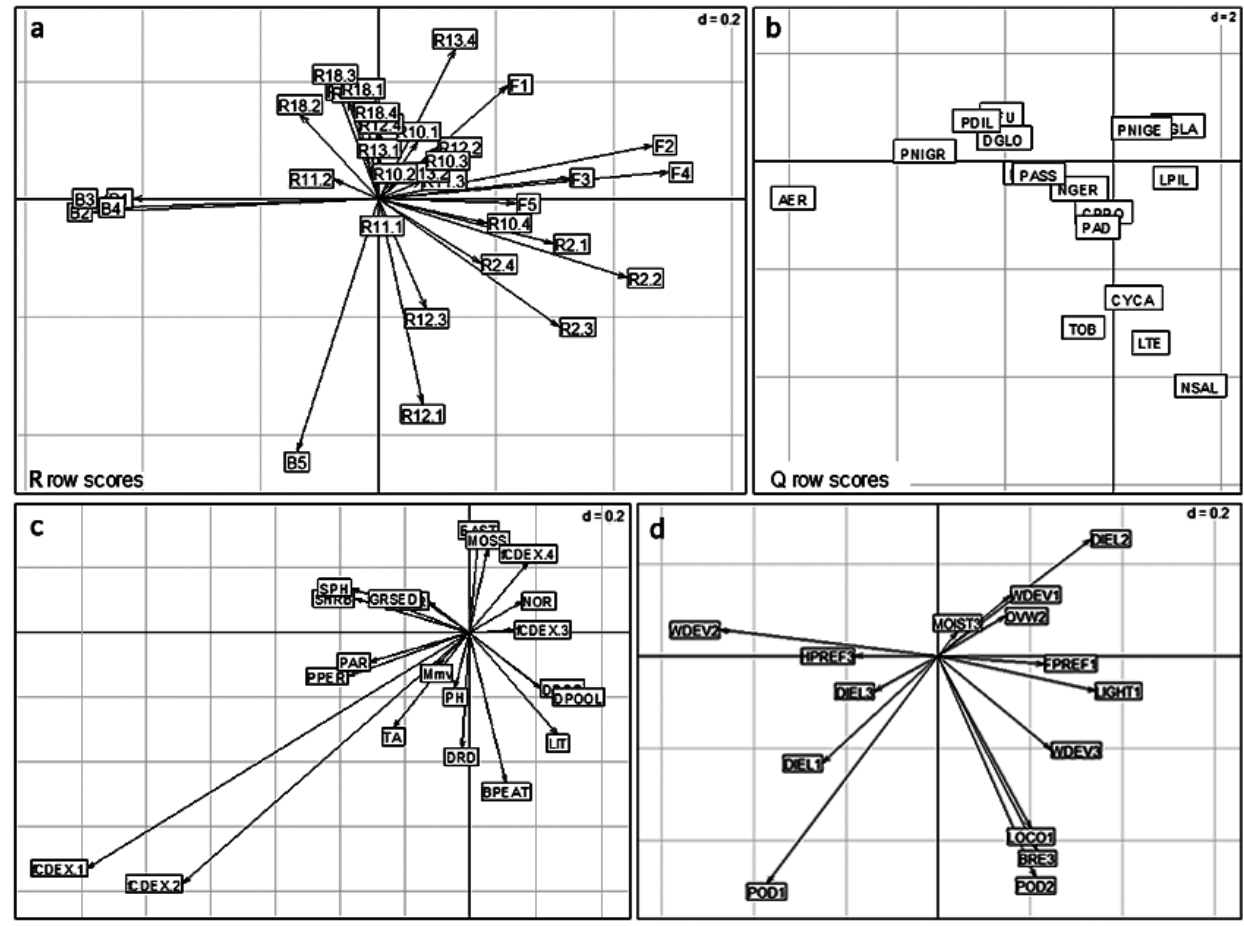

Fig. 3. Graphical summary of the RLQ analysis. a) site scores; b) carabid species scores; c) environmental variable loadings; d) carabid FT loadings. Site scores indicate restoration age class (R2-R18). Codes for carabid species are found in Table 1; codes for FTs are found in Table 2; codes for environmental variables are found in Methods. $d$ indicates grid size. 
presence of grasses and sedges. R13-R10 exhibit increasing moss cover (not restricted to Sphagnum), associated with a small group of carabids (P. niger, $C$. glabratus, L. pilicornis) that tend to prefer drier conditions and overwinter as both adults or larvae in warmer pockets of microhabitat, and which display intermediate power of dispersion via ground locomotion. A wide array of predatory carabids ( $P$. adstrictus, C. problematicus, N. germinyi, N. biguttatus, $P$. assimilis), appear to be habitat generalists. Two R12 replicates are characterised by high coverage of bare peat and presence of forest associated species, such as C. caraboides and L. terminatus, which are autumn/winter breeders with intermediate dispersal capabilities via ground locomotion. Early restoration (R2) and forestry do not show any particular association with carabid species (Figs $3 a, b$ ).

Fourth-corner tests between the first two RLQ axes for trait syndromes and environmental variables found six significant relationships. The first trait axis was significantly positively correlated with the presence of bog pools ( padj $=0.022)$ and litter (padj $=0.021)$, but negatively correlated with plot perimeter (padj $=0.006)$, plot area $($ padj $=0.046)$, shrubs $($ padj $=0.002)$ and Sphagnum cover (padj $=0.002)$ (Fig. $3 c$ ). No significant relationships were found for the second trait axis, or between functional traits and environmental variables axes were found.

\section{DISCUSSION}

Displacement of blanket bog carabid functional traits in afforested bog communities

In restoration ecology, evidence suggests that restoration usually achieves lower diversity levels and different species composition than those found in reference sites in a wide type of habitats (Moreno-Mateos et al. 2015), and that time to functional equivalency might far exceed the usual and relatively short monitoring periods (Tемperton et al. 2004). For peatland insects, the type of peatland and extent of damage can influence restoration speed and local species pool, and thus different systems can show a wide range of recovery rates. For instance, whilst ant assemblage composition can be significantly different from that at bog reference sites after a decade in Australian mined bogs (ANDERSEN et al. 2003), beetle assemblage convergence in New Zealand can be remarkably fast (2-3 years), even when low cost restoration approaches are applied (WATTs et al. 2008) despite the importance of invertebrates in ecosystem dynamics. In experimental trials in a mined peat bog in New Zealand, we compared the short-term rate of beetle community re-assembly at sites restored using management techniques varying in cost and effort to im- 
plement, and subsequently examined the long-term rate of beetle community convergence towards the 'target' community structure of an undisturbed peat bog. There was a direct relationship between the rate of beetle community re-assembly and the cost and effort applied to plant community restoration treatments (processed peat with no seed, processed peat with seed, and direct habitat translocation. Our results show that blanket bog restoration management alters carabid assemblages found in forestry plantations, but following this initial change, the difference in FTs between restoration and blanket bog carabid assemblages remains consistently different throughout the 18 year restoration chronosequence studied. This, together with the wide variation in recovery times across all these peatland studies, suggests that the convergence towards bog FTs of carabid assemblages might not be primarily dictated by time since onset of restoration, that is, it might not be a linear process in the case of carabid FTs.

A number of drivers are expected to contribute to the restoration of carabid communities and their FTs, such as habitat structure, and this is supported by RLQ results together with other variables such as distance to bog pools and plot perimeter. There are indeed examples of restoration by tree felling and ditch blocking leading to remarkably fast (1-3 years) recovery of arthropods in drained Finnish mires, particularly for tyrphobiont (bog specialist) carabids (NoreIKA et al. 2015). Such results provide some evidence that animal assemblages, and the ecosystem functions they provide (Sudduth et al. 2011), could be naturally re-established once the vegetation structure required is in place (PALMER et al. 1997) but basic research in community ecology will also benefit. We pose several major thematic questions that are relevant to restoration from the perspective of community ecological theory and, for each, identify specific areas that are in critical need of further research to advance the science of restoration ecology. We ask, what are appropriate restoration endpoints from a community ecology perspective? The problem of measuring restoration at the community level, particularly given the high amount of variability inherent in most natural communities, is not easy, and may require a focus on restoration of community function (e.g., trophic structure. In our case, and despite of nearly two decades of restoration, habitat structure might not have reached the stage in which typical blanket bog trait syndromes can occur and persist. Our findings suggest that the restoration trend observed reflects the limitations of the felling to waste and ditch blocking approach to emulate the conditions required by tyrphobiont carabids. Other studies conducted in the same site clearly support this hypothesis, whereby a forestry "legacy" effect can be observed on water table depth (WTD) and water quality (GAFFNEY et al. 2018), vegetation communities (НANCOCK et al. 2018), and a net sink carbon budget (HAMBLEY 2016), which remain different to those found in undamaged open blanket bog. 
In a complementary study we have observed that, similar to carabid FTs, the species composition of carabid communities remained different between restoration areas and open blanket bog over the same chronosequence, with communities in restoration dominated by carabid habitat generalists whilst bog communities were dominated by habitat specialists (or typrhobionts), likely linked to the provision of microhabitat via bog vegetation (PraviA 2018). For the trajectory observed in carabid FTs though, there seems to be a combination of factors at play. At a local scale, the acidic and waterlogged conditions found in blanket bog, coupled with a fluctuating WTD, are likely to attract tyrphobionts. In general, specialist species tend to be late colonisers and functionally less similar to habitat generalists (Li et al. 2015), but in blanket bog specialisation is also connected to blanket bog microhabitats created by peatland microforms (Lindsay et al. 1988). These vegetation microforms are thought to provide refuge from the variable moisture gradients linked to acute changes in WTD (e.g. Främbs et al. 1994). These particular conditions seem to favour tyrphobionts and filter out habitat generalists, whereby Sphagnum mosses primarily act as microhabitat engineers for tyrphobiont carabids (Noreika et al. 2015).

At a larger scale, variables such as habitat fragmentation and distance between restoration and undamaged bogs, may restrict species to certain micropatches of bog (NoreIKA et al. 2015), and increase the extinction risk of remaining populations (De Vries \& Den Boer 1989). Although habitat specialisation is not the only driver of species distribution in ecosystems, there is evidence across vertebrate and invertebrate taxa that specialisation increases species vulnerability to habitat changes (De Vries \& Den Boer 1989, Drees et al. 2007) and therefore cannot bridge distances that exceed 200 meters between sites suitable for reproduction. At present in Drenthe (The Netherlands, including edge effects related to habitat quality (e.g. birds, WiLson et al. 2014, MAGURA et al. 2017). This can be directly linked to species FTs via dispersal and recolonisation ability, as well as wing development or aptitude for physical movement (e.g. RINK \& Sinsch 2007); which seems to be the case for a range of further arthropods in addition to carabids (e.g. spiders, BonTe et al. 2003).

The identification of trait syndromes filtered by environmental conditions via RLQ analysis reinforces the hypothesis that microhabitat conditions are key for the distribution of carabid species. Factors such as species spillover and edge effects, whereby assemblages are influenced by incoming species from adjacent areas of different habitats, may play an important role in the distribution of some carabid species (Magura et al. 2017, Pravia 2018). However, this does not seem to be the case for the restoration trajectory of species FTs in blanket bog, which appear from our results to be largely shaped by legacy effects. 


\section{Functional diversity}

The FTs used in this study did not identify microstructural differences between treatments, although distinct trait syndromes were identified for each treatment. There are four potential explanations: (1) the FTs used did not contain information regarding species microhabitat preferences because they are not widely available in the literature, thus being unable to discern species habitat preferences at the microhabitat scale; (2) singleton carabids were excluded from the analyses as their FTs contained many missing values that can affect the results (MájeKoví et al. 2016). However these species present unique FTs in the carabid assemblage that could be of high importance in the restoration process, and removing them from the analyses may also affect our results (PAKEMAN 2014); (3) multiple interactions may influence combinations of traits that are not really reflected by the indices used to illustrate the functional structure of the community, where constraints in trait availability and confounding factors in trait analyses can be difficult to overcome without larger sample sizes; and (4) species turnover between sites had no influence on the functional structure of the carabid community (VILléger et al. 2010). Finally, the proximity of treatments and the relatively small size of the carabid species pool might have limited the statistical power of the analyses performed.

\section{Environment but not traits drive carabid species composition in peatland restoration}

The traits measured in this study were not a driver of differences in species affinities with current environmental conditions in restored blanket bog. This finding suggests that unmeasured traits may drive carabid composition. There are, however, key environmental variables that act as ecological filters of the taxonomic composition of carabid communities, though these do not affect the community's functional components. A clear separation in FTs composition, from generalist to specialised, was observed from forestry to open blanket bog, indicating that the restoration trajectory of carabid beetles might not be moving towards an open blanket bog habitat. Thus, further management interventions might be required to correct the restoration trajectory towards blanket bog and to move away from the legacy effects of forestry. Specifically, the habitat structure engineered by vegetation seems to have a strong effect on carabid community composition, and management that promotes quick recolonisation of blanket bog plant species is likely to benefit typical bog carabids. Additionally, the distance to forestry habitats was found to be a filter for carabid species, pointing to the need for blanket bog to be in close proximity to restoration sites in order to act as recolonisation sources. 
The significance of the global RLQ test, however, does not deem the aforementioned results significant, which could be due to the relatively small species pool of carabids available. This testing approach controls well for Type I errors, it has reduced power $(>0.40)$ for datasets with less than 30 species (Ter BraAK et al. 2012). However, bogs are typically species poor in comparison with other types of peatlands (BAtzer \& Boix 2016), and Forsinard seems to also display lower carabid diversity than other European bogs (e.g. BRIGić et al. 2017). This could be due to Britain's generally low diversity, or it could also be a reflection of more widespread declines in carabid species composition and abundance across the UK, which includes bogs seemingly unaffected by changes in land use (Ввоокs et al. 2012). Widespread declines could be acting in conjunction with the habitat matrix created by restoration, in which patches of blanket bog are mixed with restoration and forestry, posing a barrier for the recolonisation of carabid species affine to blanket bog that may be restricted by their FTs (e.g. low dispersal ability).

Even though this study did not find any filtering traits in the restoration of formerly afforested blanket bog for carabid communities, FTs can be a useful addition to restoration monitoring schemes, which can be exemplified by the wing development. We physically measured wing dimorphism for all carabid species in a small number of individuals, and we found that, of the six species RIBERA et al. (2001) considered dimorphic, in our study four were observed to be brachypterous and two macropterous. If such values had been used for analysis it would mean that apterous rather than macropterous carabid species would be the least represented group (25\%) in the community. Wing development is a very plastic trait in carabids (Löver \& SundeRLAND 1996) that can expressed as phenotypic plasticity between long and short-winged individuals of evolutionary importance, because it results in temporal and spatial differences in dispersal ability and even different dispersal strategies (Aukema 1990). This would be particularly relevant for tyrphobiont and tyrphophile carabid species, especially if their dispersal potential is environmentally controlled, that is, dictated by habitat quality (AuKEMA 1995), or in the case of blanket bog, habitat structure (e.g. Främbs 1994). AuKEma (1990) suggests that, under comparable stable conditions, genetically inherited wing development (fixed system) will lead to a rapid decrease of macropterous genotypes and dispersal potential, although contiguous habitat is available for colonisation between occupied parts of a site. When wing development is controlled by the environment (dynamic system), there is more flexibility for developing long-term within-site colonisation strategies (Aukema 1990). Following Aukema's hypotheses, tyrphobiont carabids in Forsinard tend to be brachypterous, suggesting that we have a dynamic system where certain environmental factors might control wing development. Conversely, the presence of macropterous species in restoration may indicate a fixed system where wing development is inherited, but changing environmen- 
tal conditions (forest-to-bog restoration) offer the possibility of colonising new niches in a less fixed system. In addition, an increasing availability of resources might in turn influence wing development, flight ability and dispersal. The fact that tyrphobionts tend to be either apterous or short-winged species reinforces the idea that microhabitat structure is likely to be of great importance for carabids. Since seasonal within-patch movement seem to be favoured by some tyrphobionts, their average dispersal distance will be considerably reduced and thus there might not be a need for wings at all once new patches are recolonised and new populations are established. What this example shows is that species FTs are very plastic and influenced by both biotic and abiotic factors, but they can also provide substantial insight into community structure, the recolonisation process and assembly rules during restoration management.

\section{CONCLUSION}

This study offers some evidence that for the recovery of arthropod communities in open blanket bog that has been converted to forestry, restoration needs to bring back key habitat characteristics partly due to the association of some specific species traits with bog habitats. Although generally trait-based approaches have proven to be a useful tool to better understand community assembly rules and the species role in ecosystem functioning, the traits measured in this study failed to show any linkages between carabids and the restoration chronosquence. This is likely due to scarcity of information available on functional traits of carabid beetles in blanket bogs, despite this being a relatively well-known taxa. Our functional approach has, nevertheless, provided an indication of what type of trait syndromes might be relevant for carabid bog assemblages, mainly driven by wing development, habitat specialisation and diel activity. Further research involving carabid microhabitat preferences and bog habitat use should further clarify the functional trait information required for a better understanding of how restoration influences carabid communities. Similar approaches could be used for sites where novel management methods are implemented to accelerate the recovery of vegetation and/ or habitat structure typical of blanket bog.

Acknowledgements - We are very grateful to FCS and Fountains Forestry for granting access to their sites, as well as RSPB for allowing us to conduct this study in their nature reserve, particularly Daniela Klein, Neil Cowie and Mark Hancock. We are also grateful to Peter Gilbert for helping out with field work, James RO Davidson for his amazing Photoshop skills, and Jenni Stockan for providing useful comments throughout the experiment. This work was possible thanks to a collaborative PhD to A. Pravia supported by The James 
Hutton Institute and The University of Highlands and Islands. This work was part-funded by the Rural \& Environment Science and Analytical Division of the Scottish Government.

\section{REFERENCES}

Andersen, A. N., Hoffmann, B. D. \& Somes, J. (2003): Ants as indicators of mine site restoration: community recovery at one of eight rehabilitation sites in central Queensland. - Ecological Management \& Restoration 4: 12-19. https://doi.org/10.1046/j.14428903.2002.00112.x

Aukema, B. (1990): Wing-length determination in two wing-dimorphic Calathus species (Coleoptera:Carabidae).-Hereditas 113: 189-202.https://doi.org/10.1111/j.1601-5223.1990. tb00084.x

AukemA, B. (1991): Fecundity in relation to wing-morph of three closely related species of the Melanocephalus group of the genus Calathus (Coleoptera: Carabidae). - Oecologia 87: 118-126. https://doi.org/10.1007/BF00323789

AukemA, B. (1995): The evolutionary significance of wing dimorphism in carabid beetles (Coleoptera: Carabidae). - Researches on Population Ecology 37: 105-110. https://doi. org/10.1007/BF02515767

Bargmann, T., Heegaard, E., Hatteland, B. A., Chipperfield, J. D. \& Grytnes, J. A. (2016): Species trait selection along a prescribed fire chronosequence. - Insect Conservation $\mathcal{E}$ Diversity 9: 446-455. https://doi.org/10.1111/icad.12182

BAtzer, D. P. \& Boix, D. (2016): Invertebrates in freshwater wetlands: an international perspective on their ecology. - Springer, New York, 645 pp.

Baulechner, D., Diekotter, T., Wolters, V. \& Jauker, F. (2019): Converting arable land into flowering fields changes functional and phylogenetic community structure in ground beetles. - Biological Conservation 231: 51-58. https://doi.org/10.1016/j.biocon.2019.01.005

De Bello, F., Lavorel, S., Díaz, S., Harrington, R., Cornelissen, J. H., Bardgett, R. D., Berg, M. P., Cipriotti, P., Feld, C. K., Hering, D., Da Silva, P. M., Potts, S. G., Sandin, L., Sousa, J. P., Storkey, J., Wardle, D. A. \& Harrison, P. A. (2010): Towards an assessment of multiple ecosystem processes and services via functional traits. Biodiversity and Conservation 19: 2873-2893. https://doi.org/10.1007/s10531-010-9850-9

Belovsky, G. E. \& Slade, J. B. (2017): Grasshoppers affect grassland ecosystem functioning: spatial and temporal variation. - Basic and Applied Ecology 26: 24-34. https://doi. org/10.1016

Benjamini, Y. \& Hochberg, Y. (1995): Controlling the false discovery rate: a practical and powerful approach to multiple testing. - Journal of the Royal Statistical Society. Series B Methodological 57: 289-300.

Bernhardt-Römermann, M., Römermann, C., Nuske, R., Parth, A., Klotz, S., Schmidt, W. \& Stadler, J. (2008): On the identification of the most suitable traits for plant functional trait analyses. - Oikos 117: 1533-1541. https://doi.org/10.1111/j.00301299.2008.16776.x

Bonte, D., Vandenbroecke, N., Lens, L. \& Maelfait, J. P. (2003): Low propensity for aerial dispersal in specialist spiders from fragmented landscapes. - Proceedings of the Royal Society of London B: Biological Sciences 270: 1601-1607. https://doi.org/10.1098/ rspb.2003.2432

Ter BraAk, C. J. F. \& Smilauer, P. (2002): CANOCO reference manual and CanoDraw for Window User's Guide: Software for canonical community ordination (version 4.5). 
Ter Braak, C. J. F., Cormont, A. \& Dray, S. (2012): Improved testing of species traits-environment relationships in the fourth-corner problem. - Ecology 93: 1525-1526. https:// doi.org/10.1890/12-0126.1

Brigić, A., Starčević, M., Hrašovec, B. \& Elek, Z. (2014a): Old forest edges may promote the distribution of forest species in carabid assemblages (Coleoptera: Carabidae) in Croatian forests. - European Journal of Entomology 111: 715-725. https://doi. org/10.14411/eje.2014.090

Brigić, A., Vujčić-Karlo, S., Alegro, A., Šegota, V. \& Ternjej, I. (2014b): Ecology, biology and conservation of Pterostichus rhaeticus Heer, 1837 (Coleoptera: Carabidae) at the edge of its distribution range in the Western Balkans. - Italian Journal of Zoology 81: 517-529. https://doi.org/10.1080/11250003.2014.947338

Brigić, A., Bujan, J., Alegro, A., Šegota, V. \& Ternjej, I. (2017): Spatial distribution of insect indicator taxa as a basis for peat bog conservation planning. - Ecological indicators 80: 344-353. https://doi.org/10.1016/j.ecolind.2017.05.007

Brooks, D. R., Bater, J. E., Clark, S. J., Monteith, D. T., Andrews, C., Corbett, S. J., Beaumont, D. A. \& Chapman, J. W. (2012): Large carabid beetle declines in a United Kingdom monitoring network increases evidence for a widespread loss in insect biodiversity. - Journal of Applied Ecology 49: 1009-1019. https://doi.org/10.1111/j.13652664.2012.02194.x

Buchanan, G. M., Grant, M. C., Sanderson, R. A. \& Pearce-Higgins, J. W. (2006): The contribution of invertebrate taxa to moorland bird diets and the potential implications of land-use management. - Ibis 148: 615-628. https://doi.org/10.1111/j.1474919X.2006.00578.x

Bullock, J. M., Aronson, J., Newton, A. C., Pywell, R. F. \& Rey-Benayas, J. M. (2011): Restoration of ecosystem services and biodiversity: conflicts and opportunities. - Trends in Ecology and Evolution 26: 541-549. https://doi.org/10.1016/j.tree.2011.06.011

Cole, L. J., McCracken, D. I., Dennis, P., Downie, I. S., Griffin, A. L., Foster, G. N., MurPHY, K. J. \& WATERHOUSE, T. (2002): Relationships between agricultural management and ecological groups of ground beetles (Coleoptera: Carabidae) on Scottish farmland. - Agriculture, Ecosystems \& Environment 93: 323-336. https://doi.org/10.1016/ S0167-8809(01)00333-4

Desrochers, A. \& Van Duinen, G. J. (2006): Peatland Fauna. - Boreal Peatland Ecosystems 188: $67-100$.

DíAz, S. \& CABIDo, M. (2001): Vive la différence: plant functional diversity matters to ecosystem processes. - Trends in Ecology \& Evolution 16: 646-655. https://doi.org/10.1016/ S0169-5347(01)02283-2

DRAY, S. \& LEGENDRE, P. (2008): Testing the species traits-environment relationships: the fourthcorner problem revisited. - Ecology 89: 3400-3412. https://doi.org/10.1890/08-0349.1

Dray, S., Choler, P., Dolédec, S., Peres'neto, P. R., Thuiller, W., Pavoine, S. \& Ter BraAk, C. J. F. (2014): Combining the fourth-corner and the RLQ methods for assessing trait responses to environmental variation. - Ecology 95: 14-21. https://doi.org/10.1890/13-0196.1

Drees, C., Matern, A., Vermeulen, R. \& Assmann, T. (2007): The influence of habitat quality on populations: a plea for an amended approach in the conservation of Agonum ericeti. - Baltic Journal of Coleopterology 7: 1-8.

Eкschmitт, K., Wolters, V. \& Weber, M. (1997): Spiders, carabids and staphylinids: the ecological potential of predatory macroarthropods. In: BecKinser, G. (ed.): Fauna in soil ecosystems. Recycling processes, nutrient fluxes and agricultural production. - Dekker, New York, 414 pp.

Forsythe, T. G. (2000): Ground beetles. - Pelagic Publishing, Richmond, 86 pp. 
Fountain-Jones, N. M., Baker, S. C. \& Jordan, G. J. (2014): Moving beyond the guild concept: developing a consistent functional trait framework for terrestrial beetles. - Ecological Entomology 40: 1-13. https://doi.org/10.1111/een.12158

Främbs, H. (1994): The importance of habitat structure and food supply for carabid beetles (Coleoptera, Carabidae) in peat bogs. - Memoirs of the Entomological Society of Canada 126: 145-159. https://doi.org/10.1007/978-1-4020-5204-0_23

Gaffney, P. J., Hancock, M. H., Taggart, M. A. \& Andersen, A. (2018): Measuring restoration progress using pore- and surface-water chemistry across a chronosequence of formerly afforested blanket bogs. - Journal of Environmental Management 219: 239-251. https://doi.org/10.1016/j.jenvman.2018.04.106

Gagic, V., Batomeus, I., Jonsson, T., Taylor, A., Winqvist, C., Fischer, C., Slade, E. M., Steffan-Dewenter, I., Emmerson, M., Potts, S. G., Tscharntke, T., Weisser, W. \& Bommarco, R. (2015): Functional identity and diversity of animals predict ecosystem functioning better than species-based indices. - Proceedings Biological Sciences 282: 20142620. https://doi.org/10.1098/rspb.2014.2620

Gallé, R., Happe, A. K., Baillod, A. B., Tscharntke, T. \& Batáry, P. (2019): Landscape configuration, organic management, and within-field position drive functional diversity of spiders and carabids. - Journal of Applied Ecology 56: 63-72. https://doi. org/10.1111/1365-2664.13257

Garnier, E., Navas, M. L. \& Grigulis, K. (2016): Plant functional diversity: organism traits, community structure and ecosystem properties. - Oxford University Press, Oxford, 231 pp.

Ghermandi, A., Van Den Bergh, J. C. J. M., Brander, L. M., De Groot, H. L. F. \& Nunes, P. A. L. D. (2010): Values of natural and human-made wetlands: A meta-analysis. Water Resources Research 46: W12516. https://doi.org/10.1029/2010WR009071

Gerisch, M., Agostinelli, V., Henle, K. \& Dziock, F. (2012): More species, but all do the same: contrasting effects of flood disturbance on ground beetle functional and species diversity. - Oikos 121: 508-515. https://doi.org/10.1111/j.1600-0706.2011.19749.x

Gerisch, M. (2014): Non-random patterns of functional redundancy revealed in ground beetle communities facing an extreme flood event. - Functional Ecology 28: 1504-1512. https://doi.org/10.1111/1365-2435.12272

Gerlach, J., Samways, M. \& Pryke, J. (2013): Terrestrial invertebrates as bioindicators: An overview of available taxonomic groups. - Journal of Insect Conservation 17: 831-850. https://doi.org/10.1007/s10841-013-9565-9

Gotelli, N. J. \& Graves, G. R. (1996): Null models in ecology. - Smithsonian Institution Press. http://www.uvm.edu/ ngotelli/nullmodelspage.html (accessed August 2017)

Grime, J. P. (1998): Benefits of plant diversity to ecosystems: immediate, filter and founder effects. - Journal of Ecology 86: 902-910. https://doi.org/10.1046/j.1365-2745.1998.00306.x

Haapalehto, T. O., Vasander, H., Jauhiainen, S., Tahvanainen, T. \& Kotiaho, J. S. (2011): The effects of peatland restoraiton on water table depth, elemental concentrations and vegetation: 10 years of changes. - Restoration Ecology 19: 587-598. https://doi. org/10.1111/j.1526-100X.2010.00704.x

Hambley, G. (2016): The effect of forest-to-bog restoration on net ecosystem exchange in The Flow country peatlands. - PhD thesis, University of Stirling.

Hancock, M. H., Klein, D., Andersen, R. \& Cowie, N. R. (2018): Vegetation response to restoration management of a blanket bog damaged by drainage and afforestation. Applied Vegetation Science 21: 167-178. https://doi.org/10.1111/avsc.12367

Hunter, M. D., Adl, S., Pringle, C. M. \& Coleman, D. C. (2003): Relative effects of macroinvertebrates and habitat on the chemistry of litter during decomposition. - Pedobiologia 47: 101-115. https://doi.org/10.1078/0031-4056-00174 
Ings, T. C. \& Hartley, S. E. (1999): The effect of habitat structure on carabid communities during the regeneration of a native Scottish forest. - Foresty Ecology and Management 119: 123-126. https://doi.org/10.1016/S0378-1127(98)00517-9

Koivula, M. J., Kuккоnen, J. \& Niemelä, J. (2002): Boreal carabid-beetle (Coleoptera, Carabidae) assemblages along the clear-cut originated succession gradient. - Biodiversity and Conservation 11: 1269-1288. https://doi.org/10.1023/A:1016018702894

Koivula, M. J. \& Vermeulen, H. J. W. (2005): Highways and forest fragmentation - effects on carabid beetles (Coleoptera, Carabidae). - Landscape Ecology 20: 911-926. https:// doi.org/10.1007/s10980-005-7301-x

Kulkarni, S. S., Dosdall, L. M. \& Willenborg, C. J. (2015): The role of ground beetles (Coleoptera: Carabidae) in weed seed consumption: A review. - Weed Science 63: 355-376. https://doi.org/10.1614/WS-D-14-00067.1

Laliberté, A. E. \& Legendre, P. (2010): A distance-based framework for measuring functional diversity from multiple traits. - Ecology 91: 299-305. https://doi.org/10.1890/082244.1

Laliberté, A. E., Legendre, P. \& Shipley, B. (2015): Package FD. Available at: https://cran.rproject.org/web/packages/FD/FD.pdf

Legendre, P. \& Gallagher, E. D. (2001): Ecologically meaningful transformation for ordination of species data. - Oecologia 129: 271-280. https://doi.org/10.1007/s004420100716

Li, S., Cadotte, M. W., Meiners, S. J., Hua, Z., Jiang, L. \& Shu, W. (2015): Species colonisation, not competitive exclusion, drive community overdispersion over long-term succession. - Ecology Letters 18: 964-973. https://doi.org/10.1111/ele.12476

Lindsay, R., Charman, D. J., Everingham, F., O'Reilly, R. M., Palmer, M. A., Rowell, T. A. \& Stroud, D. A. (1988): The Flow Country: the peatlands of Caithness and Sutherland. - Joint Nature Conservation Committee. http://roar.uel.ac.uk/1155/

Lövei, G. L. \& Sunderland, K. D. (1996): Ecology and behavior of ground beetles (Coleoptera: Carabidae). - Annual Review of Entomology 41: 231-256. https://annualreviews. org/doi/abs/10.1146/annurev.en.41.010196.001311

Luff, M. L. (2007): The Carabidae (ground beetles) of Britain and Ireland. RES handbooks for the identification of British Insects, Vol 4, Part 2. - Field Studies Council, 252 pp.

Magura, T. (2017): Ignoring functional and phylogenetic features masks the edge influence on ground beetle diversity across forest-grassland gradient. - Forest Ecology and Management 384: 371-377. https://doi.org/10.1016/j.foreco.2016.10.056

Magura, T., Tóthmérész, B. \& Elek, Z. (2003): Diversity and composition of carabids during a forestry cycle. - Biodiversity and Conservation 12: 73-85. https://doi. org/10.1023/A:1021289509500

Magura, T. \& Lövei, G. L. (2019): Environmental filtering is the main assembly rule of ground beetles in the forest and its edge but not in the adjacent grassland. - Insect Science 26: 154-163. https://doi.org/10.1111/1744-7917.12504

Májeková, M., Paal, T., Plowman, N. S., Bryndová, M., Kasari, L., Norberg, A., Weiss, M., Bishop, T. R., Luke, S. H., SAM, K., Le Bagousse-Pinguet, Y., Lepš, J., Götzenberger, L. \& De Bello, F. (2016): Evaluating functional diversity: missing trait data and the importance of species abundance structure and data transformation. - PLOS ONE 11: e0149270. https://doi.org/10.1371/journal.pone.0149270

Manly, B. F. J. (1995): A note on the analysis of species co-occurrences. - Ecology 76: 11091115. https://doi.org/10.2307/1940919

Mason, N. W. H, Mouillot, D., Lee, W. G. \& Wilson, J. B. (2005): Functional richness, functional and functional evenness divergence: the primary of functional components diversity. - Oikos 111: 112-118. https://doi.org/10.1111/j.0030-1299.2005.13886.x 
McGill, B. J., Enquist, B. J., Weiner, E. \& Westoby, M. (2006): Rebuilding community ecology from functional traits. - Trends in Ecology and Evolution 21: 178-185. https://doi. org/10.1016/j.tree.2006.02.002

McLean, E. O. (1982): Soil pH and lime requirement. In: Page, A. L. (ed.): Methods of soil analysis, Part 2. Chemical and microbiological properties. - Soil Science Society of America, Madison, $224 \mathrm{pp}$.

Moreno-Mateos, D., Meli, P., Vara-Rodríguez, M. I. \& Aronson, J. (2015): Ecosystem response to interventions: lessons from restored and created wetland ecosystems. Journal of Applied Ecology 52: 1528-1537. https://doi.org/10.1111/1365-2664.12518

Mouchet, M. A., Villéger, S., Norman, W. H. M. \& Mouillot, D. (2010): Functional diversity measures: An overview of their redundancy and their ability to discriminate community assembly rules. - Functional Ecology 24: 867-876. https://doi.org/10.1111/ j.1365-2435.2010.01695.x

Mouillot, D., Graham, N. A. J., Villéger, S., Mason, N. W. H. \& Bellwood, D. R. (2013): A functional approach reveals community responses to disturbances. - Trends in Ecology \& Evolution 28: 167-177. https://doi.org/10.1016/j.tree.2012.10.004

New, T. R. (2004): Insects, fire and conservation. - Springer, Switzerland, 208 pp.

Nolte, D., Schuldt, A., Gossner, M. M., Ulrich, W. \& Assmann, T. (2017): Functional traits drive ground beetle community structures in Central European forests: Implications for conservation. - Biological Conservation 213: 5-12. https://doi.org/10.1016/j. biocon.2017.06.038

Noordijk, J., Schaffers, A. P. \& SyкоRA, K. V. (2008): Diversity of ground beetles (Coleoptera: Carabidae) and spiders (Araneae) in roadside verges with grey hair-grass vegetation. - European Journal of Entomology 105: 261-265.

Noreika, N., Kotiaho, J. S., Penttinen, J., Punttila, P., Vuori, A., Pajunen, T., Autio, O., LouкоцA, O. J. \& Kотze, D. J. (2015): Rapid recovery of invertebrate communities after ecological restoration of boreal mires. - Restoration Ecology 23: 566-579. https:// doi.org/10.1111/rec.12237

Oksanen, J., Blanchet, F. G., Kindt, R., Legendre, P., Minchin, P. R., O'Hara, R. B., Simpson, G. L., Solymos, P., Stevens, M. H. H. \& Wagner, H. (2018): Vegan: community ecology package. R package version 2.5-1. http://CRAN.R-project.org/package=vegan (accessed 15 May 2018)

Pakeman, R. J. (2011): Functional diversity indices reveal the impacts of land use intensification on plant community assembly. - Journal of Ecology 99: 1143-1151. https://doi. org/10.1111/j.1365-2745.2011.01853.x

PAKEMAN, R. J. (2014): Functional trait metrics are sensitive to the completeness of the species' trait data?. - Methods in Ecology and Evolution 5: 9-15. https://doi.org/10.1111/2041210X.12136

Palmer, M. A., Ambrose, R. F. \& Poff, N. L. R. (1997): Ecological theory and community restoration ecology. - Restoration Ecology 5: 291-300. https://doi.org/10.1046/j.1526100X.1997.00543.X

Petchey, O. L. \& Gaston, K. J. (2006): Functional diversity: Back to basics and looking forward. - Ecology Letters 9: 741-758. https://doi.org/10.1111/j.1461-0248.2006.00924.x

Pravia, A. (2018): The response of arthropod assemblages to peatland restoration in formerly afforested blanket bog. - PhD Thesis, University of Aberdeen-University of the Highlands and Islands. https://ethos.bl.uk/OrderDetails.do?did=1\&uin=uk.bl.ethos.767340

R Core Tеam (2017): R: a language and environment for statistical computing. R Foundation for Statistical Computing, Vienna, Austria. https://www.Rproject.org/ 
Ramchunder, S. J., Brown, L. E. \& Holden, J. (2012): Catchment-scale peatland restoration benefits stream ecosystem biodiversity. - Journal of Applied Ecology 49: 182-191. https://doi.org/10.1111/j.1365-2664.2011.02075.x

Ribera, I., Foster, G. N., Downie, I. S., McCracken, D. I. \& Abernethy, V. J. (1999): A comparative study of the morphology and life traits of Scottish ground beetles (Coleoptera, Carabidae). - Annales Zoologici Fennici 36: 21-37

Ribera, I., Dolédec, S., Downie, I. S. \& Foster, I. (2001): Effect of land disturbance and stress on species traits of ground beetle assemblages. - Ecology 82: 1112-1119. https:// doi.org/10.1890/0012-9658(2001)082[1112:EOLDAS]2.0.CO;2

RINK, M. \& Sinsch, U. (2007): Radio-telemetric monitoring of dispersing stag beetles: implications for conservation. - Journal of Zoology 272: 235-243. https://doi.org/10.1111/ j.1469-7998.2006.00282.x

Rochefort, L. \& ANDERSEN, R. (2017): Global peatland restoration after 30 years: where are we in this mossy world? - Restoration Ecology 25: 269-270. https://doi.org/10.1111/rec.12417

SpITZer, K. \& Danks, H. V. (2006): Insect biodiversity of boreal peat bogs. - Annual Review of Entomology 51: 137-161. https://doi.org/10.4039/entm119140163-1

Stockan, J. A., Baird, J., Langan, S. J., Young, M. R. \& Iason, G. R. (2014): Effects of riparian buffer strips on ground beetles (Coleoptera, Carabidae) within an agricultural landscape. - Insect Conservation \& Diversity 7: 172-184. https://doi.org/10.1111/icad.12043

Sudduth, E. B., Hassett, B. A., Cada, P. \& Bernhardt, E. S. (2011): Testing the Field of Dreams Hypothesis: functional responses to urbanization and restoration in stream ecosystems. - Ecological Applications 21: 1972-1988. https://doi.org/10.1890/10-0653.1

Thiele, H. (2012): Carabids in their environments. Springer, Berlin Heidelberg, 372 pp.

Swenson, N. G. (2014): Functional and phylogenetic ecology in R. - Springer, New York, 212 pp.

Temperton, V. M., Hobbs, R. J., Nuttle, T. \& Halle, S. (2004): Assembly rules and restoration ecology: Bridging the gap between theory and practice. - Island Press, $464 \mathrm{pp}$.

Turin, H. \& Den Boer, P. J. (1988): Changes in the distribution of carabid beetles in The Netherlands since 1880. II. Isolation of habitats and long-term time trends in the occurrence of carabid species with different powers of dispersal (Coleoptera, Carabidae). - Biological Conservation 44: 179-200. https://doi.org/10.1016/0006-3207(88)90101-2

Villéger, S., Ramos Miranda, J., Flores Hernández, D. \& Mouillot, D. (2010): Contrasting changes in taxonomic vs. functional diversity of tropical fish communities after habitat degradation. - Ecological Applications 20: 1512-1522. https://doi.org/10.1890/09-1310.1

De Vries, H. H. \& Den Boer, P. J. (1989): Survival of populations of Agonum ericeti Panz. (Coleoptera, Carabidae) in relation to fragmentation of habitats. - Netherlands Journal of Zoology 40: 484-498. https://doi.org/10.1007/978-94-017-0968-2_39

Watts, C. H., Clarkson, B. R. \& Didham, R. K. (2008): Rapid beetle community convergence following experimental habitat restoration in a mined peat bog. - Biological Conservation 141: 568-579. https://doi.org/10.1016/j.biocon.2007.12.008

Weiner, E., Clarke, P. \& Keddy, P. A. (1998): Community assembly rules, morphological dispersion, of plant species the coexistence. - Oikos 81: 309-322. https://doi. org/10.1111/1365-2435.12345

Wilson, J. D., Anderson, R., Bailey, S., Chetcuti, J., Cowie, N. R., Hancock, M. H., Quine, C. P., Russell, N., Stephen, L. \& Thompson, D. B. A. (2014): Modelling edge effects of mature forest plantations on peatland waders informs landscape-scale conservation. - Journal of Applied Ecology 51: 204-213. https://doi.org/10.1111/1365-2664.12173

Received March 14, 2019, accepted March 31, 2019, published November 22, 2019 